\title{
Assessment and Distribution of Heavy Metals Pollutants in Manzala Lake, Egypt
}

\author{
Mahmoud Abd El-Kawy Zahran', Yasser Ahmed El-Amier1, Abdelhamid Ahmed Elnaggar², \\ Hoda Abd El-Azim Mohamed ${ }^{3}$, Muhammad Abd El-Hady El-Alfy ${ }^{3}$ \\ ${ }^{1}$ Botany Department, Faculty of Science, Mansoura University, Mansoura, Egypt \\ ${ }^{2}$ Soils Department, Faculty of Agriculture, Mansoura University, Mansoura, Egypt \\ ${ }^{3}$ Marine Pollution Department, National Institute of Oceanography and Fisheries, Suez, Egypt \\ Email: yasran@mans.edu.eg
}

Received 24 May 2015; accepted 23 August 2015; published 26 August 2015

Copyright (C) 2015 by authors and Scientific Research Publishing Inc.

This work is licensed under the Creative Commons Attribution International License (CC BY).

http://creativecommons.org/licenses/by/4.0/

(c) (i) 0 pen Access

\begin{abstract}
Contamination with heavy metals is one of the most serious problems in the aquatic environments. In Egypt, Manzala Lake is suffering from this problem. The objective of this work was to assess heavy metals pollutants and their spatial distribution in Manzala Lake using GIS technique. Georeferenced water and sediment samples were randomly collected from the lake. The detected heavy metals were: $\mathrm{Fe}, \mathrm{Pb}, \mathrm{Cu}, \mathrm{Cd}, \mathrm{Cr}, \mathrm{Zn}$ and $\mathrm{Co}$. The obtained results indicated that the highest concentrations of heavy metals were observed in the northeastern and the southern parts of the lake nearby drains. This could be attributed to industrial, agricultural and municipal wastes coming through the drains especially Bahr El-Baqar drain and the industrial wastes coming from Port Said drains. From the geo-accumulation index, it was noticed that the lake is more polluted with cadmium and lead in the hydrosoils samples. All metals in water are within the EPA standard limit except for cadmium. Geostatistics provides effective methods to quantify the contaminated waters and sediments which support decision-making about redevelopment scenarios or remediation techniques.
\end{abstract}

Keywords

Manzala Lake, Heavy Metals, Indices, Pollution, GIS

\section{Introduction}

The contamination by heavy metals in the aquatic environments has drawn particular attentions due to their toxicity, persistence and biological accumulation. Heavy metals have low solubility and primarily get absorbed and 
accumulated on bottom sediments. Bottom lake sediments are sensitive indicators for monitoring pollutants as they act as a sink and a carrier for contaminants in aquatic environment. The most anthropogenic sources of metals are industrial, petroleum contamination and sewage disposal [1]. Manzala Lake, the largest of Egypt's Mediterranean wetlands and the most productive for fisheries, is suffering from land reclamation, industrial and nutrient pollution and overgrowth by water hyacinth. In the last six decades Manzala Lake was subjected to various threats: agriculture drainage, municipal sewage and industrial waste water. These pollutants have turned the lake into polluted, unhealthy ecosystem affecting fish production and natural resources that are distributed within the lake. A total of fresh water (mostly from agricultural drainage) flow annually into Manzala Lake from nine major drains and canals. It receives and carries the greatest part of wastewater into the lake through a very densely populated area of the Eastern Delta passing through Qalubyia, Sharkia, Ismailia and Port Said Governorates, and contributing much to the deteriorating water quality of the lake. Due to the toxicity of heavy metals, accurate information about their concentrations in aquatic ecosystem is needed. Accordingly, the objective of this study is to assess and evaluate the heavy metals pollutants in Lake Manzala using heavy metals indices with integrating GIS techniques for distribution of heavy metals in water and hydrosoils and joining them with their sources.

\section{Materials and Methods}

\subsection{Study Area}

Manzala Lake is the largest lake in the northern region of Egypt and the most productive for fisheries. The lake, as illustrated in Figure 1, lies between $31^{\circ} 45^{\prime}, 32^{\circ} 15^{\prime} \mathrm{E}$ and $31^{\circ} 00^{\prime}, 31^{\circ} 35^{\prime} \mathrm{N}$. It covers an area of about 52,611 hectares. It is bordered by Suez Canal from east, Nile-Damietta branch from west and Mediterranean Sea from north. It is a shallow lagoon where about $50 \%$ of the lake area has a depth ranged between 0.5 and $1.0 \mathrm{~m}$. The lake receives polluted water from different drains namely; Bahr El-Baqar, Ramsis, El-Matria, Hadous, Faraskur, El-Serw and Lissa El-Gamalia.

\subsubsection{Climate}

The climate of the Mediterranean coastal region of Egypt is belonging to the dry arid climatic zone. The study area lies in Meig's warm coastal deserts in which summer is warmest season with mean temperature less than $30^{\circ} \mathrm{C}$, and winter is the coldest season with mean temperature above $10^{\circ} \mathrm{C}$. The mean minimum air temperature at Manzala Lake ranged between $8.4^{\circ} \mathrm{C}$ in January and $21.4^{\circ} \mathrm{C}$ in August with mean annual temperature of about $15.4^{\circ} \mathrm{C}$, and the mean maximum air temperature varies from $18.3^{\circ} \mathrm{C}$ in January to $31^{\circ} \mathrm{C}$ in August with mean annual temperature of $24.9^{\circ} \mathrm{C}$. The relative humidity ranges from $68 \%$ in May to $76 \%$ in August with a mean annual value of $72 \%$. The total annual rainfall attains a value of $106.7 \mathrm{~mm}$. while the evaporation rate varies from
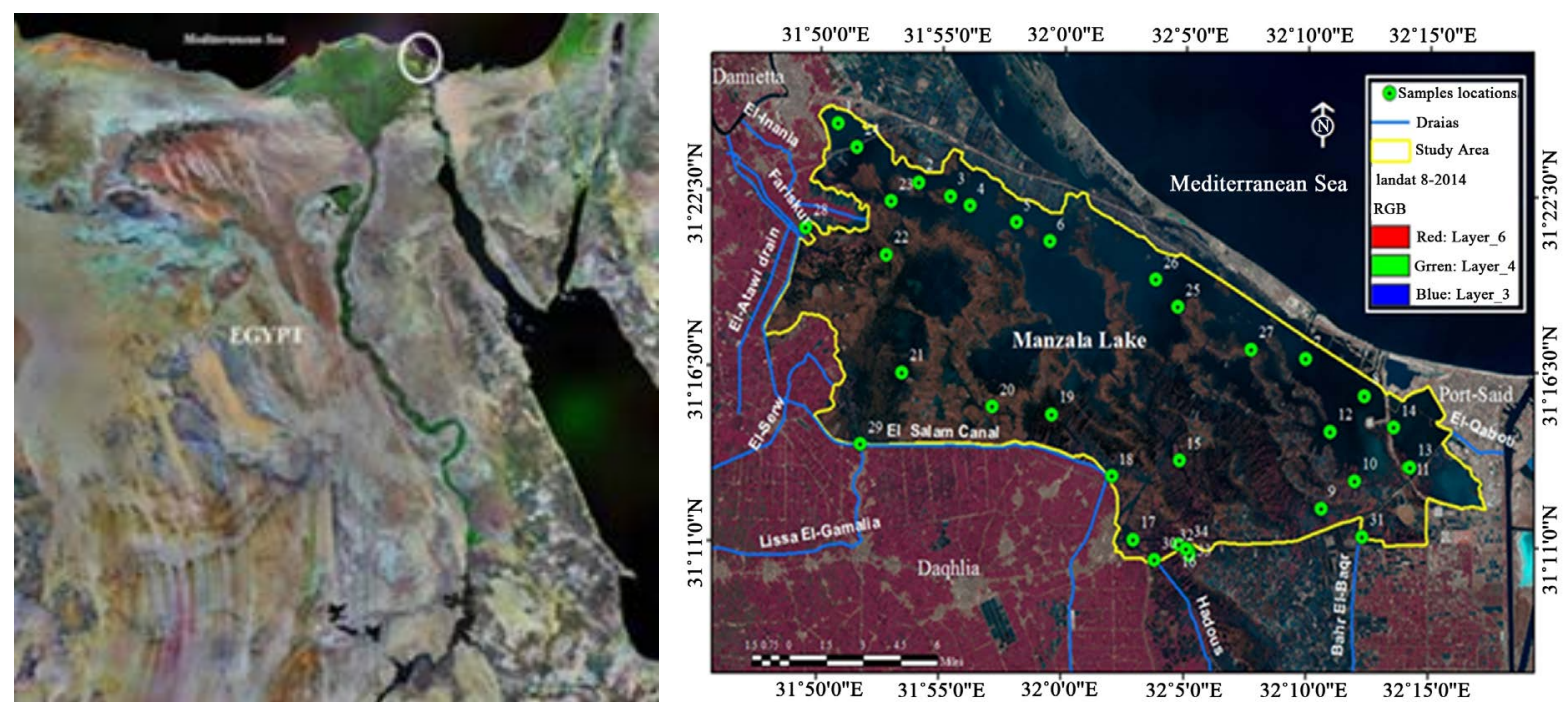

Figure 1. Location map of Manzala Lake and sampling locations. 
$2.8 \mathrm{~mm} /$ day in December and July to $5.4 \mathrm{~mm} /$ day in June. The prevailing wind is South westerly in January and February; North and north west in April, May, June, July, August and September; North easterly in October and November; and South westerly in December.

\subsubsection{Water Resources}

The lake is connected to the Mediterranean Sea via three outlets permitting exchange of water and biota between the lake and the sea, these outlets are El-Gamil, El-Boughdady and the new El-Gamil [2]. There is a small canal (El-Qaboty canal) that link between the lake and Suez Canal. There are major drains and canals flow into Lake Manzala as follows:

- Faraskur: Agricultural drain, serves 20,000 feddans, an area of about $44.48 \mathrm{~km}^{2}$ (4\% of total inflow).

- El-Sirw: Agriculture drain, serves 68,700 feddans $\left(152.8 \mathrm{~km}^{2}\right), 13 \%$ of total inflow.

- Matariya: It serves 50,000 of land under agricultural reclamation (2\%).

- Ramsis: Discharges a relatively small amount of water to Manzala Lake $\left(24 \mathrm{~km}^{2}\right)$.

- Hadous: Is the largest drain in the eastern delta, serving some of agricultural land of about $1756.96 \mathrm{~km}^{2}$ (49\%).

- Bahr El-Baqar: Serves an agricultural area of about $119.2 \mathrm{~km}^{2}$, and receives about 300 million $\mathrm{m}^{3} /$ year of treated and untreated sewage from Cairo ( $25 \%$ of total inflow).

\subsection{Samples}

Thirty-four hydrosoil samples and thirty one water samples were randomly collected from different sites within the lake as illustrated in (Figure 1). Geographic positions of these samples were appointed using the GPS device (Garmin, etrex model). The collected samples were sent to the laboratory for heavy metal analysis. Seven essential heavy metals were studied in this work. These elements were $\mathrm{Fe}, \mathrm{Pb}, \mathrm{Cu}, \mathrm{Cd}, \mathrm{Zn}, \mathrm{Cr}$ and $\mathrm{Co}$.

\subsection{Analytical Methods}

\subsubsection{The Analysis of the Dissolved Heavy Metals in Water Samples}

Surface water samples were collected and then stored in acid-washed polyethylene bottles for analyses. Then, these samples were filtered using $0.45 \mathrm{um}$ membrane filters. All the precautions occurred to minimize risks of sample contamination were followed during collection and treatment of samples. Solvent extraction was utilized using ammonium pyrrolidinedi-thiocarbamate (APDC) and methyl isobutyl ketone (MIBK). Where, water samples were pre-concentrated with APDC-MIBK extraction procedure according to the standard methods [3]. Heavy metals in the obtained solution were measured using the Flame Atomic Absorption Spectrophotometer (AAS: Perkin Elmer Analyst 100).

\subsubsection{The Analysis of Heavy Metals in Hydrosoils Samples}

Hydrosoil samples were collected using a Van-Veen grab coated with polyethylene. Sub-samples were taken from the central part of the grab to avoid contamination. The samples were kept in self-sealed acid pre-cleaned plastic bags, rinsed with metal-free water. The samples were deep-frozen until analysis. The samples were dried in the oven at $70^{\circ} \mathrm{C}$ and sieved using $0.75 \mathrm{~mm}$ plastic sieve and digested for about two hours in a mixture of 3:2:1 $\mathrm{HNO}_{3}, \mathrm{HCLO}_{4}$ and $\mathrm{HF}$ acids, respectively as described by Oregioni and Astone [4].

\subsection{Geostatistics}

The Geostatistical analyst in ArcGIS (ver. 10.1) software package was used to develop the ordinary Kriging method and the semivariogram between each pairs of points versus their separation distances [5]. This semivariogram was used in predicting the studied heavy metals in both waters and sediments of Manzala Lake.

\subsection{Heavy Metals Indices in Hydrosoil Samples}

\subsubsection{Enrichment Factor (EF)}

Enrichment Factor is considered as an effective tool to evaluate the magnitude of contaminants in the environment. Iron (Fe) was chosen as the controlling element [6]. The EF values $<2$ indicate that the metal is entirely from crustal materials or natural processes; whereas EF values $>2$ suggest that the sources are more likely to be 
anthropogenic [7].

$$
\text { Enrichment Factor }=(\mathrm{M} / \mathrm{Fe}) \text { sample } /(\mathrm{M} / \mathrm{Fe}) \text { background }
$$

where, $\mathrm{M}$ is the concentration of metal. The background value is that of avera.ge shale. Six categories are recognized: $\leq 1$ background concentration, 1 - 2 depletion to minimal enrichment, 2 - 5 moderate enrichment, 5 - 20 significant enrichment, 20 - 40 very high enrichment and $>40$ extremely high enrichment.

\subsubsection{Contamination Factor (CF)}

The CF is the ratio obtained by dividing the concentration of each metal in the sediment by the baseline or Background value [8].

$$
\text { Contamination Factor }(\mathrm{CF})=\mathrm{C} \text { metal/C background }
$$

The following terminologies are used to describe the contamination factor: $\mathrm{CF}<1$ (low contamination factor); $1 \leq \mathrm{CF}<3$ (moderate contamination factors); $3 \leq \mathrm{CF}<6$ (considerable contamination factors) and $\mathrm{CF} \geq 6$ (very high contamination factor).

\subsubsection{Pollution Load Index (PLI)}

The PLI of a single site is the root of number $(n)$ of multiplied together Contamination Factor (CF) values.

$$
\mathrm{PLI}=\left(\mathrm{CF}_{1} * \mathrm{CF}_{2} * \mathrm{CF}_{3} * \cdots * \mathrm{CF}_{n}\right)^{1 / n}
$$

where, $n$ is the number of metals (seven in the present study) and CF is the contamination factor. A PLI value of zero indicates perfection; a value of one indicates the presence of only baseline levels of pollutants, and values above one would indicate progressive deterioration of the site quality [9] [10].

\subsubsection{Degree of Contamination (DC)}

The degree of contamination (DC) defined as the sum of all contamination factors for a given site:

$$
\mathrm{Cd}=\sum_{i=1}^{n} \mathrm{CFi}
$$

where CF is the single contamination factor and $\mathrm{n}$ is the count of the elements present. DC values less than $n$ would indicate low degree of contamination; $n \leq \mathrm{DC}<2 n$, moderate degree of contamination; $2 n \leq \mathrm{DC}<4 n$, considerable degree of contamination; and DC $>4 n$, very high degree of contamination. Where, $\mathrm{n}=7=$ the count of the studied heavy metals.

\subsubsection{Geo-Accumulation Index (Igeo)}

An index of geo-accumulation (Igeo) was originally defined by Müller [11] to determine and define the metal contamination in sediments by comparing current concentrations with pre-industrial levels.

$$
\text { Igeo }=\log 2\left(\frac{\mathrm{Cn}}{1.5 \mathrm{Bn}}\right)
$$

where, $\mathrm{Cn}$ is the measured concentration of heavy metals in sediments, $\mathrm{Bn}$ is the geochemical background value in average shale of element $\mathrm{n}$ and 1.5 is the background matrix correction due to anthropogenic influences. The geo-accumulation index (Igeo) was distinguished into seven classes by Buccolieri et al. [12]: Igeo $\leq 0$, class 0 , unpolluted; $0<$ Igeo $\leq 1$, class 1 , from unpolluted to moderately polluted; $1<$ Igeo $\leq 2$, class 2 , moderately polluted; $2<$ Igeo $\leq 3$, class 3 , from moderately to strongly polluted; $3<$ Igeo $\leq 4$, class 4 , strongly polluted; $4<$ Igeo $\leq 5$, class 5 , from strongly to extremely polluted; and Igeo $>5$, class 6 , extremely polluted.

\section{Results and Discussion}

Metals generally enter the aquatic environment through erosion of the geological matrix, or due to anthropogenic activities caused by industrial effluents, domestic sewage, and mining wastes. Lead and Cadmium are toxic to living organisms even at quite low concentrations, whereas others, such as $\mathrm{Zn}$ and $\mathrm{Cu}$, are biologically essential and natural constituents of aquatic ecosystems, and generally only become toxic at very high concentrations. 


\subsection{Heavy Metals in Water of Manzala Lake}

The concentrations of dissolved heavy metals in water samples of Manzala Lake between different habitats are as shown in Table 1. Figures 2(a)-(g) illustrates the spatial distribution of dissolved heavy metals in the water samples collected from Manzala Lake. The mean concentration of the measured metals in water was found to be in the following sequence; $\mathrm{Fe}>\mathrm{Zn}>\mathrm{Pb}>\mathrm{Co}>\mathrm{Cu}>\mathrm{Cd}>\mathrm{Cr}$.

Table 1. The concentrations of dissolved heavy metals in the water of Manzala Lake.

\begin{tabular}{|c|c|c|c|c|c|c|c|c|c|}
\hline Site no. & $\mathrm{X}$ & $\mathrm{Y}$ & $\mathrm{Fe}$ & $\mathrm{Zn}$ & $\mathrm{Pb}$ & $\mathrm{Cu}$ & Co & $\mathrm{Cr}$ & $\mathrm{Cd}$ \\
\hline 1 & 31.402 & 31.845 & 13.65 & 5.773 & 3.808 & 1.229 & 1.269 & 0.33 & 0.932 \\
\hline 2 & 31.372 & 31.901 & 34.73 & 7.423 & 6.463 & 2.728 & 1.597 & 0.63 & 0.887 \\
\hline 3 & 31.365 & 31.923 & 17.57 & 8.612 & 4.712 & 1.868 & 1.896 & 0.416 & 0.891 \\
\hline 4 & 31.360 & 31.936 & 24.58 & 8.519 & 4.871 & 1.892 & 3.077 & 0.492 & 0.902 \\
\hline 5 & 31.352 & 31.968 & 17.71 & 7.292 & 4.954 & 1.617 & 1.673 & 0.454 & 0.941 \\
\hline 6 & 31.342 & 31.990 & 20.16 & 6.741 & 2.694 & 1.683 & 1.645 & 0.951 & 0.725 \\
\hline 7 & 31.282 & 32.166 & 14.06 & 9.976 & 5.482 & 1.468 & 1.621 & 0.721 & 0.785 \\
\hline 8 & 31.262 & 32.206 & 20.89 & 9.506 & 3.794 & 2.113 & 1.689 & 0.359 & 0.802 \\
\hline 9 & 31.204 & 32.177 & 11.405 & 5.375 & 5.5 & 1.15 & 0.975 & 1.27 & 0.225 \\
\hline 10 & 31.218 & 32.200 & 41.52 & 3.265 & 3.93 & 0.655 & 0.775 & 1.1 & 0.23 \\
\hline 11 & 31.225 & 32.237 & 32.115 & 5.58 & 9.15 & 0.98 & 1.395 & 1.98 & 5.5 \\
\hline 12 & 31.244 & 32.183 & 20.56 & 3.935 & 5.225 & 1.38 & 1.765 & 1.66 & 4.67 \\
\hline 13 & 31.225 & 32.237 & 14.17 & 5.98 & 3.75 & 1.265 & 1.775 & 22.1 & 3.93 \\
\hline 14 & 31.246 & 32.226 & 17.4 & 3.15 & 5.19 & 1.24 & 1.925 & 4.015 & 9.15 \\
\hline 15 & 31.228 & 32.080 & 12.315 & 1.18 & 5.95 & 0.64 & 0.85 & 0.46 & 2.09 \\
\hline 16 & 31.184 & 32.080 & 19.87 & 1.635 & 1.925 & 1.14 & 1.005 & 0.3 & 3.75 \\
\hline 17 & 31.186 & 32.049 & 17.05 & 1.305 & 1.805 & 0.72 & 0.995 & 1.84 & 5.19 \\
\hline 18 & 31.220 & 32.034 & 12.395 & 1.365 & 2.21 & 0.605 & 0.805 & 0.095 & 0.245 \\
\hline 19 & 31.251 & 31.993 & 7.38 & 1.495 & 1.595 & 0.515 & 0.705 & 0.34 & 0.27 \\
\hline 20 & 31.255 & 31.952 & 4.785 & 1.14 & 3.25 & 1.03 & 0.685 & 0.45 & 0.29 \\
\hline 21 & 31.273 & 31.890 & 9.055 & 1.17 & 2.505 & 0.695 & 0.71 & 0.24 & 0.28 \\
\hline 22 & 31.334 & 31.879 & 11.4 & 1.34 & 4.56 & 1.05 & 2.324 & 0.23 & 0.275 \\
\hline 23 & 31.362 & 31.882 & 12.98 & 1.32 & 5.63 & 1.65 & 0.86 & 0.25 & 0.275 \\
\hline 24 & 31.390 & 31.858 & 13.34 & 1.12 & 6.46 & 1.76 & 1.552 & 0.35 & 0.285 \\
\hline 25 & 31.308 & 32.078 & 15.62 & 5.605 & 8.234 & 1.776 & 1.765 & 0.65 & 0.924 \\
\hline 26 & 31.322 & 32.063 & 17.95 & 6.34 & 3.992 & 1.392 & 2.103 & 0.86 & 0.802 \\
\hline 27 & 31.286 & 32.129 & 21.48 & 4.56 & 7.374 & 3.793 & 2.369 & 1.23 & 1.212 \\
\hline 28 & 31.348 & 31.823 & 183.3 & 11.77 & 6.12 & 4.879 & 6.557 & 0.973 & 0.987 \\
\hline 29 & 31.235 & 31.862 & 167.4 & 11.91 & 6.73 & 4.775 & 5.937 & 0.633 & 0.325 \\
\hline 30 & 31.176 & 32.064 & 42.73 & 7.069 & 3.58 & 2.996 & 6.557 & 0.252 & 0.805 \\
\hline \multirow[t]{4}{*}{31} & 31.189 & 32.205 & 47.74 & 9.465 & 4.77 & 2.947 & 7.15 & 0.592 & 0.748 \\
\hline & Mean & & 29.59 & 5.19 & 4.72 & 1.73 & 2.13 & 1.49 & 1.59 \\
\hline & $\mathrm{SE}( \pm)$ & & 7.24 & 0.61 & 0.33 & 0.20 & 0.33 & 0.70 & 0.37 \\
\hline & EPA, 2002 & & 300 & 5000 & 50 & 50 & & 100 & 2.37 \\
\hline
\end{tabular}

EPA (2002): Environmental Protection Agency limit for water \& values in $(\mu \mathrm{g} / \mathrm{l})$. 

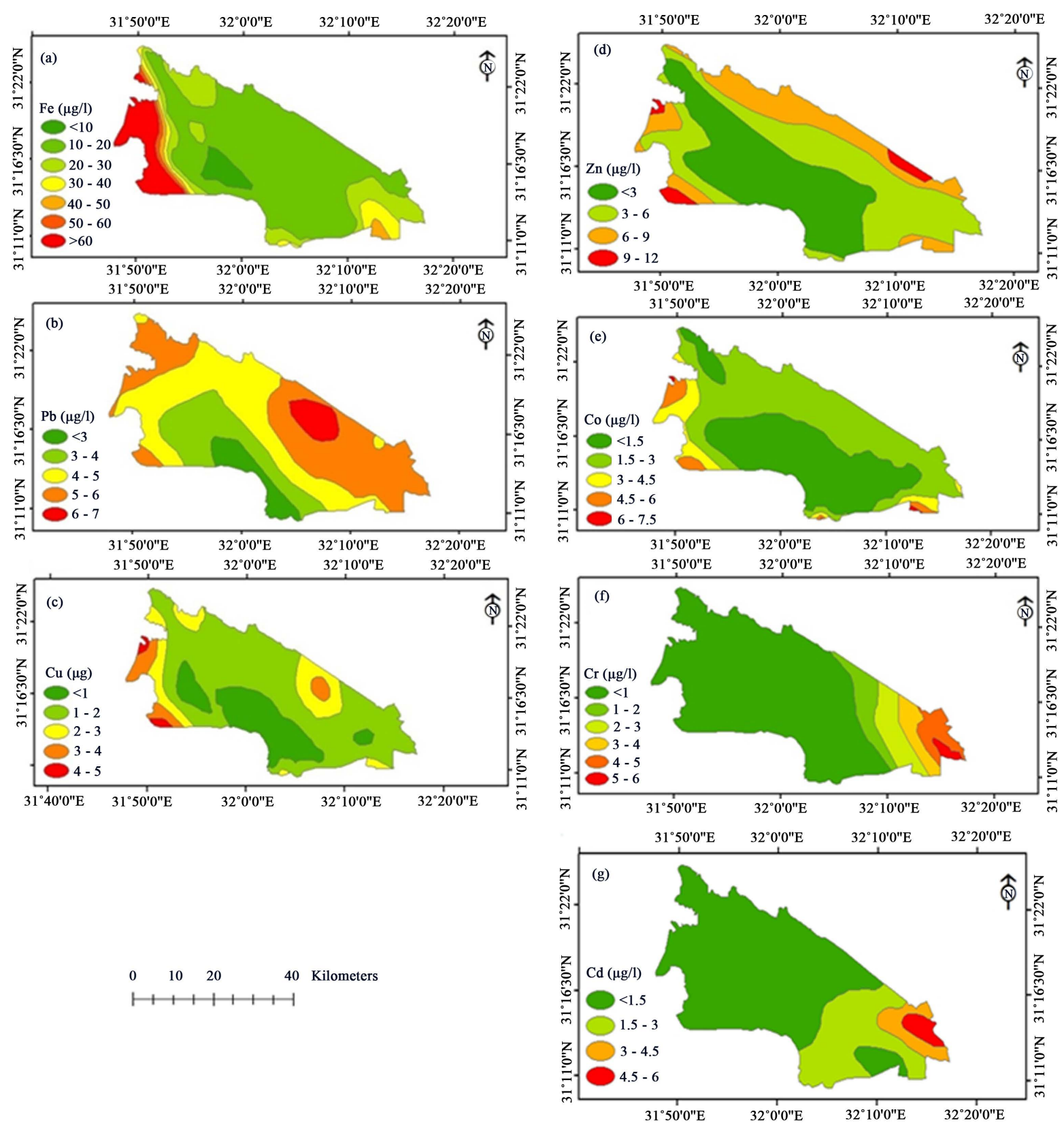

Figure 2. The spatial distribution of (a) iron; (b) lead; (c) copper; (d) zinc; (e) cobalt; (f) chromium and (g) cadmium in the water samples of Manzala Lake using GIS technique.

Iron varied from $4.78 \mu \mathrm{g} / \mathrm{l}$ nearby El-Gamalia city to $183.3 \mu \mathrm{g} / \mathrm{l}$ at Faraskur drain. This result is lower than those $(1420 \mu \mathrm{g} / \mathrm{l}-696 \mu \mathrm{g} / \mathrm{l})$ recorded by Saeed and Shaker [1] and El-Alfy [13]. While the concentration of copper varied from 0.51 to 4.87 at Faraskur drain. The highest concentrations of iron and copper are distributed at the southwestern parts of lake especially nearby drains, where there are more agricultural wastes as revealed by Arain et al. [14]. The concentrations of dissolved Fe in the oxygen depleted waters were markedly higher than those found in the oxic northern waters of Manzala Lake "i.e. nearby El-Boughaz area" [9]. Higher values of $\mathrm{Cu}$ in Manzala Lake were observed in both water and hydrosoil by Ali and Abdel-Satar [15].

Zinc is one of the most abundant toxic heavy metals, the oral toxicity of humans to most zinc compounds is relatively low. High concentrations of zinc in the marine environment may exist from the discharge of industrial wastes especially electroplating and synthetic fiber production. It ranged between 1.12 and $11.91 \mu \mathrm{g} / \mathrm{l}$. It's noti- 
ceable that the highest concentrations of zinc were observed as well at the drains and nearby industrial areas as a result to direct discharge of industrial wastes in these areas. However, the lowest concentration of zinc is distributed in the middle part of the lake far from drains. These values are lower than that recorded by Bahnsawy et al. [16].

Dissolved lead in water ranged between 1.59 to $8.23 \mu \mathrm{g} / \mathrm{l}$. The lowest concentration of lead was recorded far away from drainage areas, but the highest concentration was observed at northeastern side nearby the industrial compound. These areas receive huge quantities of sewage and industrial wastes, as well as from spill of leaded petrol from fishing boats and dust which holds a huge amount of lead [10]. The present result of lead in water is within the limit of EPA [10]. The United States Environmental Protection Agency EPA [18] has classified Pb as being potentially hazardous and toxic to most forms of life.

Cobalt was in the range between 0.68 to $7.15 \mu \mathrm{g} / \mathrm{l}$. The lower concentrations of cobalt are distributed at the middle and northern parts of the Lake. The highest concentration of cobalt was recorded nearby drains at the southern parts as a result of agricultural wastes especially Bahr El-Baqar drain. This result agreed with Nagpal, [19].

The sources of chromium entering the aquatic environment are from paint and chemical works, oil drilling and recovery rigs. Large quantities of chromium may be released from petrochemical industries and cement, fertilizer, power, and chlor-alkali plants. It varied from 0.09 to $22.10 \mu \mathrm{g} / \mathrm{l}$. The highest concentration of $\mathrm{Cr}$ is found at Ashtoum El-Gamil area, near tourist villages and Company of Natural gas Petroget. Furthermore, untreated domestic sewage was discharged into the sea from activities at the coastal area [20]. The lowest concentration of $\mathrm{Cr}$ is obtained nearby Hadous drain. The highest concentration in Manzala is higher than the threshold limit (1.5 $\mu \mathrm{g} / \mathrm{l})$ of Environment Canada [21], but is within EPA limit [10].

Cadmium is one of the black listed elements, it can be considered as one of the most dangerous elements on marine life and humans. The dissolved cadmium in water of Manzala Lake is in the range between 0.22 to 9.15 $\mu \mathrm{g} / \mathrm{l}$. The lowest concentration was recorded at open water far from drains, but the highest concentration was recorded nearby El-Qaboty area south to port said city as a result of urban extension and agricultural disposal especially the phosphatic fertilizers, this is in agreement with Bahnasawy et al. [17]; El-Serehy et al. [20] and Hamed et al. [22]. The estimated Cd value in this study is more than the EPA limits [10]. It is one of the most toxic elements with widespread carcinogenic effects in humans and considered to be toxic if its concentration exceeds $0.01 \mathrm{mg} / \mathrm{L}$ both in drinking and irrigation water.

\subsection{Heavy Metals in the Hydrosoils of Manzala Lake}

Hydrosoil contamination poses one of the worst environmental problems in ecosystems, acting as sinks and sources of contaminants in aquatic systems. Hydrosoil analyses play an important role in assessing the pollution status of the environment. The concentrations of heavy metals in the hydrosoils of Manzala Lake are as given in Table 2 and the spatial distribution is illustrated in Figures 3(a)-(g). The concentrations of heavy metals in the hydrosoils of Manzala Lake take the following sequence; $\mathrm{Fe}>\mathrm{Cr}>\mathrm{Zn}>\mathrm{Pb}>\mathrm{Cu}>\mathrm{Co}>\mathrm{Cd}$, which except Fe differs from these of the lake's water.

Iron in the hydrosoils of Manzala Lake was in the range between 250 and $666.37 \mu \mathrm{g} / \mathrm{g}$. Where copper varied from 1.25 to $52.68 \mu \mathrm{g} / \mathrm{g}$. The highest value of iron was recorded at Bahr El-Baqar drain. For copper the highest concentration was recorded at Hadous drain. These drains have agricultural drainage, industrial and domestic wastes. These results are in agreement with those obtained by Saeed and Shaker [1] and El-Alfy [13]. It was found that those drains are rich in organic carbon and some authors found a correlation between the concentration of heavy metals in sediment and the abundance of organic matter [13]. Whereas the lowest values of iron were recorded far away from drains, nearby El-Boughaz area and the northern parts of the Lake. For copper, the lowest value was recorded at El-Temsah area far away from drains as well. The values of copper are higher than that recorded by Hamed et al. [22]. The maximum values of iron and copper in hydrosoils exceed the limits set by EPA [10] where the guideline values are 15 and $25 \mu \mathrm{g} / \mathrm{g}$ for iron and copper, respectively.

The range of lead in the hydrosoils of Manzala Lake was between 3.44 and $65.53 \mu \mathrm{g} / \mathrm{g}$. The maximum concentration of lead was recorded nearby the drains, as they receive huge quantities of sewage and industrial wastes, beside agricultural drainage water via Bahr El-Baqar drain and may attributed to the decaying of plankton and precipitation of organic matter associated with $\mathrm{Pb}$ and $\mathrm{Cd}$ to the sediment [17]. The lowest concentration of lead was noticed at El-Temsah area (at the northern parts of the lake far from drainage water). The maximum value of lead is higher than EPA limit [10], but within the limit of EU [23]. 
Table 2. The concentrations of heavy metals in the hydrosoils of Manzala Lake.

\begin{tabular}{|c|c|c|c|c|c|c|c|c|c|}
\hline Site no. & $\mathrm{X}$ & $\mathrm{Y}$ & $\mathrm{Fe}$ & $\mathrm{Zn}$ & $\mathrm{Cr}$ & $\mathrm{Cu}$ & $\mathrm{Pb}$ & Co & $\mathrm{Cd}$ \\
\hline 1 & 31.402 & 31.845 & 301.60 & 26.85 & 27.51 & 8.80 & 11.27 & 8.51 & 1.40 \\
\hline 2 & 31.372 & 31.901 & 250.00 & 4.76 & 4.52 & 1.25 & 3.44 & 2.97 & 0.66 \\
\hline 3 & 31.365 & 31.923 & 306.10 & 6.75 & 66.24 & 8.21 & 14.11 & 13.91 & 1.46 \\
\hline 4 & 31.360 & 31.936 & 271.70 & 5.75 & 8.80 & 2.21 & 5.53 & 3.32 & 0.74 \\
\hline 5 & 31.352 & 31.968 & 305.40 & 12.79 & 42.72 & 10.72 & 12.18 & 12.34 & 1.37 \\
\hline 6 & 31.342 & 31.990 & 298.50 & 22.22 & 27.86 & 6.59 & 9.62 & 7.50 & 1.16 \\
\hline 7 & 31.282 & 32.166 & 290.50 & 2.98 & 54.46 & 10.05 & 19.01 & 9.70 & 2.04 \\
\hline 8 & 31.262 & 32.206 & 306.50 & 78.06 & 39.73 & 7.08 & 14.36 & 14.48 & 1.56 \\
\hline 9 & 31.204 & 32.177 & 310.30 & 3.38 & 38.80 & 30.14 & 17.27 & 20.24 & 1.31 \\
\hline 10 & 31.218 & 32.200 & 294.10 & 75.65 & 12.41 & 9.72 & 65.53 & 6.79 & 1.19 \\
\hline 11 & 31.225 & 32.237 & 306.80 & 4.07 & 62.98 & 2.50 & 3.80 & 19.01 & 1.23 \\
\hline 12 & 31.244 & 32.183 & 307.20 & 28.10 & 28.76 & 9.46 & 63.12 & 14.36 & 2.65 \\
\hline 13 & 31.225 & 32.237 & 303.20 & 6.01 & 5.78 & 3.46 & 12.52 & 12.52 & 1.91 \\
\hline 14 & 31.246 & 32.226 & 306.40 & 3.85 & 67.49 & 9.46 & 4.70 & 15.16 & 2.71 \\
\hline 15 & 31.228 & 32.080 & 308.80 & 3.18 & 21.19 & 28.61 & 15.36 & 17.20 & 1.94 \\
\hline 16 & 31.184 & 32.080 & 306.90 & 3.02 & 16.27 & 24.40 & 23.70 & 15.92 & 2.17 \\
\hline 17 & 31.186 & 32.049 & 307.50 & 3.02 & 16.88 & 26.33 & 36.51 & 18.04 & 1.78 \\
\hline 18 & 31.220 & 32.034 & 304.90 & 2.51 & 9.41 & 21.63 & 22.29 & 16.37 & 2.38 \\
\hline 19 & 31.251 & 31.993 & 308.10 & 2.59 & 9.31 & 25.52 & 19.97 & 17.91 & 2.56 \\
\hline 20 & 31.255 & 31.952 & 301.50 & 3.35 & 2.64 & 16.85 & 21.21 & 14.05 & 2.30 \\
\hline 21 & 31.273 & 31.890 & 309.20 & 3.51 & 24.88 & 33.25 & 14.82 & 19.88 & 2.33 \\
\hline 22 & 31.334 & 31.879 & 305.40 & 3.08 & 22.23 & 17.62 & 21.10 & 15.13 & 1.96 \\
\hline 23 & 31.362 & 31.882 & 305.30 & 2.43 & 22.62 & 17.14 & 12.50 & 14.88 & 1.49 \\
\hline 24 & 31.390 & 31.858 & 305.20 & 2.84 & 21.87 & 21.59 & 20.66 & 5.51 & 2.06 \\
\hline 25 & 31.308 & 32.078 & 308.80 & 69.36 & 31.50 & 12.64 & 24.52 & 16.61 & 2.82 \\
\hline 26 & 31.322 & 32.063 & 309.10 & 77.13 & 29.73 & 13.85 & 25.57 & 15.65 & 2.82 \\
\hline 27 & 31.286 & 32.129 & 309.30 & 157.70 & 37.85 & 14.14 & 23.36 & 16.02 & 2.73 \\
\hline 28 & 31.348 & 31.823 & 630.44 & 50.84 & 37.48 & 10.81 & 22.06 & 6.56 & 0.56 \\
\hline 29 & 31.235 & 31.862 & 661.21 & 85.77 & 86.09 & 42.47 & 26.45 & 5.94 & 0.66 \\
\hline 30 & 31.176 & 32.064 & 654.77 & 72.61 & 101.50 & 52.68 & 20.44 & 6.56 & 0.88 \\
\hline 31 & 31.189 & 32.205 & 666.37 & 71.21 & 101.40 & 50.36 & 20.70 & 7.15 & 1.07 \\
\hline 32 & 31.180 & 32.087 & 299.50 & 19.00 & 14.51 & 18.80 & 33.50 & 7.59 & 1.16 \\
\hline 33 & 31.178 & 32.087 & 301.30 & 19.50 & 16.00 & 14.44 & 47.54 & 11.76 & 2.62 \\
\hline \multirow[t]{6}{*}{34} & 31.182 & 32.085 & 299.40 & 54.81 & 15.23 & 12.14 & 18.65 & 7.49 & 1.26 \\
\hline & Mean & & 342.98 & 29.08 & 33.14 & 17.50 & 21.39 & 12.27 & 1.73 \\
\hline & $\mathrm{SE}( \pm)$ & & 19.84 & 6.34 & 4.51 & 2.20 & 2.44 & 0.86 & 0.12 \\
\hline & Average Shale & & 47200 & 95 & 90 & 45 & 20 & 19 & 0.30 \\
\hline & EPA, 2002 & & 15 & 123 & 25 & 25 & 10 & - & 6 \\
\hline & EU, 2002 & & - & 300 & 150 & 140 & 300 & 11.6 & 3 \\
\hline
\end{tabular}

EPA: Environmental Protection Agency for sediment samples in ( $\mu \mathrm{g} / \mathrm{g})$; EU: European Union Standard in ( $\mu \mathrm{g} / \mathrm{g})$. 

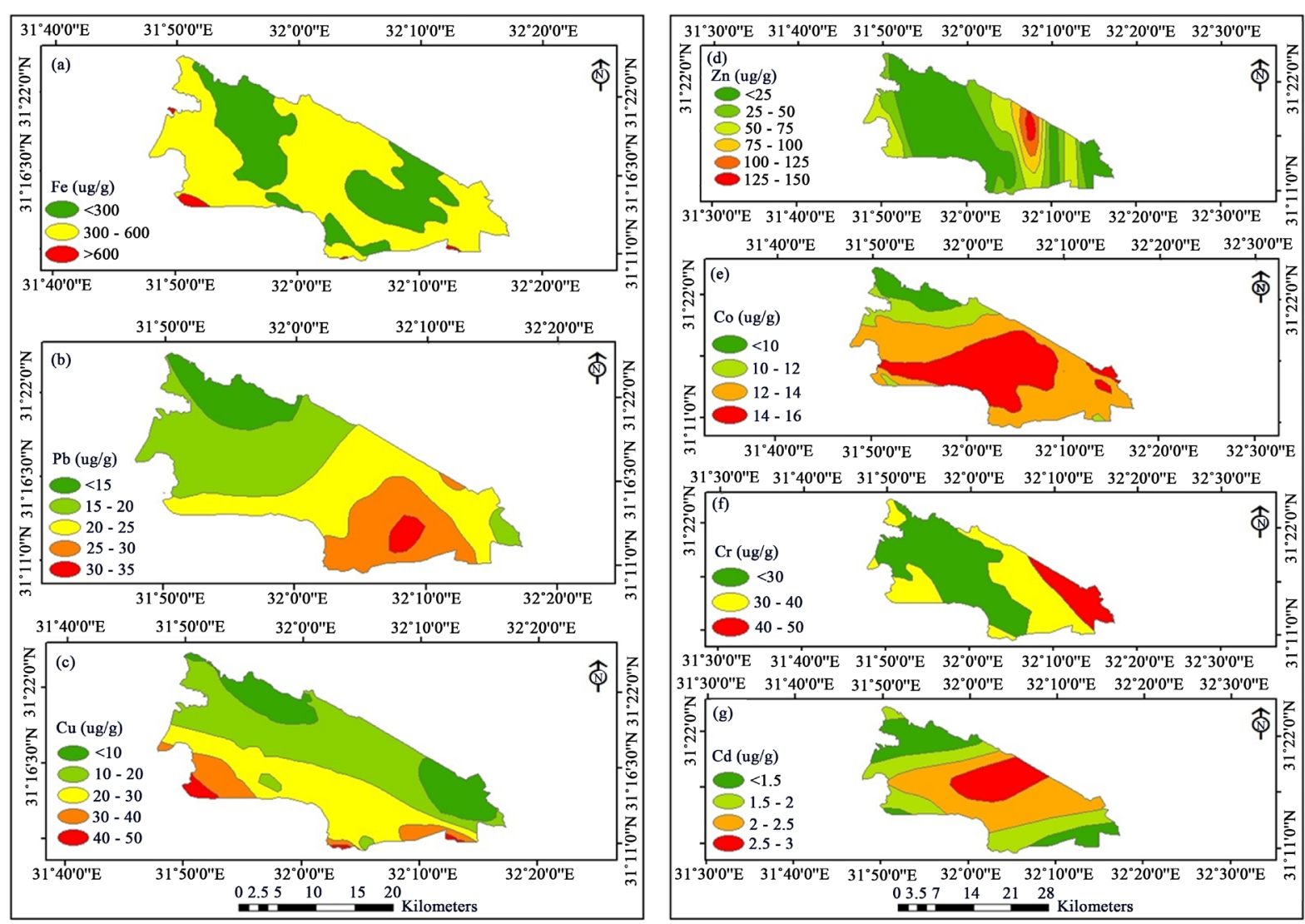

Figure 3. The spatial distribution of (a) iron; (b) lead; (c) copper; (d) zinc (e) cobalt; (f) chromium and (g) cadmium in the hydrosoils of Manzala Lake.

Zinc varied from 2.43 to $157.70 \mu \mathrm{g} / \mathrm{g}$, its highest concentration may be as a result of industrial disposal spilled directly or indirectly to the lake. The maximum concentration of Zinc in hydrosoils was obtained nearby the industrial compound northern to Lake Manzala. This result is higher than those recorded by Hamed et al. [22] and El-Alfy [13]. The lowest value of Zn was estimated at the western part of the lake far from industrial wastes. It's obvious that $\mathrm{Cd}$ and $\mathrm{Pb}$ accumulation decreased in saline medium while the accumulation of $\mathrm{Zn}$ increased so the highest concentration of zinc in the hydrosoil especially in the northern parts where sea water intrusion occurs [24]. The maximum values of zinc are more than the EPA limit, but within the limit of EU [23].

The concentration of cobalt in the hydrosoils of Manzala Lake was in the range of ( 2.79 to $20.24 \mu \mathrm{g} / \mathrm{g}$ ). Its maximum concentration was observed nearby Damietta city which may due to the irrigation of agricultural lands with untreated water and uses of agricultural fertilizers. Also high concentrations of Co were observed nearby Bahr El-Baqar drain. Its lowest value was recorded at the northwestern part of the lake far away from drains. These values were lower than (54.29 to $80.30 \mu \mathrm{g} / \mathrm{g}$ ) recorded by El-Bady [25] at Bahr El-Baqar region. Cobalt in the hydrosoils of Manzala Lake recorded values more than the EU limit [23].

Chromium varied from 2.64 to $101.50 \mu \mathrm{g} / \mathrm{g}$. The lowest concentration of $\mathrm{Cr}$ was recorded far away from drains. While the highest concentration was observed nearby drains (especially, Bahr El-Baqar and Hadous drains), the areas south to Port Said city near the industrial activities [19]. Also, high concentrations of Cr were found at Ashtoum El-Gamil area and near tourist villages and Company of Natural gas Petroget. Furthermore, untreated domestic sewage was discharged into this area from activities at the coastal area, the combustion of coal and oil. Chromium is within the limit of EU [23], but its maximum value is more than what be revealed by the EPA limit [10].

Cadmium in the hydrosoils varied from 0.56 to $2.82 \mu \mathrm{g} / \mathrm{g}$. The lowest concentration was recorded at Faraskur drain. However, the higher concentrations were concentrated in the area nearby the industrial activities. The previous results are in agreement with those obtained by Bahnasawy et al. [17] and Hamed et al. [22]. They re- 
ported that the high concentrations in this area were due to the paint factories disposal without treatment directly to the lake. Cadmium recorded higher values than the sediment quality guidelines and agreed with Saeed and Shaker [1]. The values of cadmium in hydrosoils are within EPA [10] limit of a guide value (6 $\mu \mathrm{g} / \mathrm{g})$. Cadmium in uncontaminated soils must not exceed $0.7 \mathrm{ppm}$.

\subsection{Indices of Heavy Metals in the Hydrosoils of Manzala Lake}

\subsubsection{The Enrichment Factor}

The Enrichment Factors of heavy metals in the hydrosoils of Manzala Lake are as shown in Table 3; it's indicated that the EF of $\mathrm{Cu}$ ranged between 5.24 and 112.79. For Zn, the EF varied from 3.95 to 253.32 and EF of $\mathrm{Cr}$ varied from 4.59 to 115.53. The EF of $\mathrm{Pb}$ varied from 32.51 to 484.91 and for $\mathrm{Co}$, it varied from 22 to 160 and EF of Cd varied from 140.25 to 1435.26. From the previous results, it's obvious that the EF of all metals is in the high significant categories and the sources of these metals in Lake Manzala are almost from anthropogenic activities. The sequence of EF for heavy metals in the hydrosoils of Manzala Lake is: $\mathrm{Cd}>\mathrm{Pb}>\mathrm{Zn}>$ $\mathrm{Co}>\mathrm{Cr}>\mathrm{Cu}$. From that, cadmium is more abundant than other metals; whereas $\mathrm{Cu}$ showed the lowest appearance.

\subsubsection{Contamination Factor}

From Table 4, the CF values of Fe showed low contamination factor. It ranged between low at all sites for copper and moderate CF at Hadous and Bahr El-Baqar Drains as (CF > 1). For Cr, CF is lower than 1 (low CF) and $>1$ only in the northern part of the Lake. CF of lead varied from 0.17 to 3.28 (low to considerable CF). The values of CF for cobalt are $<1$ in all sites (low CF) and $>1$ only nearby Bahr El-Baqar drain (moderate CF). The CF of cadmium showed moderate, considerable and very high CF.

\subsubsection{Pollution Load Index (PLI) and Degree of Contamination (DC)}

The PLI and DC are indicated in Table 4, where the PLI in this study area of Manzala Lake ranged between 0.11 and 0.57 . This showed that there is no appreciable pollution in Lake Manzala with those metals. From the results of contamination degree (Table 4), it ranged between low to moderate degree of pollution. The spatial distribution of DC is illustrated in Figure 4.

\subsubsection{The Geo-Accumulation Index (Igeo)}

The results of Igeo are as shown in Table 5 and Figure 5. The negative values of $\mathrm{Fe}, \mathrm{Cr}, \mathrm{Co}, \mathrm{Cu}$ and $\mathrm{Zn}$ and according to the classification of Muller [26], it indicated that the Lake isn't polluted with those metals. From the geo-accumulation index results, Igeo values of lead showed unpolluted to moderately polluted categories nearby the biological treatment project east to Port Said City, at the southern part of the Lake nearby Drains and at Ibn-Salam area (nearby Hadous drain). The Igeo results of cadmium also showed moderately polluted category in all locations.

\subsection{The Correlation between Heavy Metals in Water and Hydrosoils}

From Table 6, there are significant positive correlation between $\mathrm{Fe}$ in hydrosoil with $\mathrm{Cu}, \mathrm{Cr}$ in hydrosoil $(\mathrm{r}=$ $0.7)$; Fe, $\mathrm{Zn}$ and $\mathrm{Co}$ in water ( $\mathrm{r}=0.7,0.5$ and 0.9$)$ and correlates negatively with $\mathrm{Co}$ and $\mathrm{Cd}$ in hydrosoil as $\mathrm{r}=$ -0.4 for each. Copper in hydrosoil showed a positive significant correlation with $\mathrm{Cr}$ in hydrosoil and $\mathrm{Co}$ in water where ( $\mathrm{r}=0.5$ for each). Zinc in hydrosoil correlated with $\mathrm{Cr}$ in hydrosoil, Fe, Co and $\mathrm{Zn}$ in water $(\mathrm{r}=0.4)$ and with $\mathrm{Cu}$ in water $(\mathrm{r}=0.6)$. $\mathrm{Cr}$ in hydrosoil correlated with $\mathrm{Fe}$ in water $(\mathrm{r}=0.37)$, $\mathrm{Cu}$ in water $(\mathrm{r}=0.49), \mathrm{Zn}$ in water $(r=0.54)$ and Co in water $(r=0.7)$. Cobalt in hydrosoil showed only significant positive correlation with $\mathrm{Cd}$ in hydrosoil $(\mathrm{r}=0.6)$ and negative with $\mathrm{Fe}, \mathrm{Cu}, \mathrm{Zn}$ and $\mathrm{Co}$ in water as $(\mathrm{r}=-0.44,-0.53,-0.54$ and -0.53 respectively). Also cadmium in hydrosoil showed negative significant correlation with $\mathrm{Fe}, \mathrm{Cu}, \mathrm{Zn}$ and $\mathrm{Co}$ in water $(\mathrm{r}=-0.54,-0.47,-0.58$ and -0.51 respectively). There are a significant positive correlation between iron in water and $\mathrm{Cu}, \mathrm{Zn}$ and $\mathrm{Co}$ in water $(\mathrm{r}=0.8,0.6$ and 0.7$)$. $\mathrm{Cu}$ in water and $\mathrm{Zn}, \mathrm{Pb}$ and $\mathrm{Co}$ in water $(\mathrm{r}=0.7$, 0.4 and 0.8). Between $\mathrm{Zn}$ and $\mathrm{Co}$ in water $(r=0.6)$ and $\mathrm{Cr}$ and $\mathrm{Cd}$ in water $(r=0.36)$. Other relations between elements showed low or no significant correlations. It's obvious that the heavy metals with positive correlation were considered to have similar sources as estimated by Dan et al. [27]. 
Table 3. The enrichment factor (EF) of heavy metals in the hydrosoils of Manzala Lake.

\begin{tabular}{|c|c|c|c|c|c|c|c|}
\hline \multirow{2}{*}{ NO } & \multicolumn{7}{|c|}{ Enrichment Factor (EF) } \\
\hline & $\mathrm{Fe}$ & $\mathrm{Cu}$ & $\mathrm{Zn}$ & $\mathrm{Cr}$ & $\mathrm{Pb}$ & Co & $\mathrm{Cd}$ \\
\hline 1 & 1.00 & 30.60 & 44.23 & 47.84 & 88.19 & 70 & 727.72 \\
\hline 2 & 1.00 & 5.24 & 9.46 & 9.49 & 32.51 & 30 & 412.84 \\
\hline 3 & 1.00 & 28.13 & 10.96 & 113.49 & 108.79 & 113 & 748.37 \\
\hline 4 & 1.00 & 8.53 & 10.51 & 16.98 & 48.02 & 30 & 427.35 \\
\hline 5 & 1.00 & 36.82 & 20.81 & 73.36 & 94.12 & 100 & 705.78 \\
\hline 6 & 1.00 & 23.16 & 36.98 & 48.95 & 76.05 & 62 & 609.83 \\
\hline 7 & 1.00 & 36.29 & 5.10 & 98.32 & 154.43 & 83 & 1103.23 \\
\hline 8 & 1.00 & 24.23 & 126.54 & 67.98 & 110.57 & 117 & 799.24 \\
\hline 9 & 1.00 & 101.88 & 5.41 & 65.58 & 131.35 & 162 & 664.72 \\
\hline 10 & 1.00 & 34.67 & 127.80 & 22.13 & 525.84 & 57 & 638.75 \\
\hline 11 & 1.00 & 8.56 & 6.59 & 107.66 & 29.23 & 154 & 629.23 \\
\hline 12 & 1.00 & 32.32 & 45.45 & 49.11 & 484.91 & 116 & 1357.10 \\
\hline 13 & 1.00 & 11.99 & 9.86 & 9.99 & 97.49 & 103 & 991.53 \\
\hline 14 & 1.00 & 32.40 & 6.25 & 115.53 & 36.19 & 123 & 1391.96 \\
\hline 15 & 1.00 & 97.18 & 5.12 & 35.99 & 117.43 & 138 & 986.39 \\
\hline 16 & 1.00 & 83.39 & 4.89 & 27.80 & 182.25 & 129 & 1112.97 \\
\hline 17 & 1.00 & 89.81 & 4.88 & 28.79 & 280.21 & 146 & 909.21 \\
\hline 18 & 1.00 & 74.41 & 4.09 & 16.19 & 172.53 & 133 & 1230.18 \\
\hline 19 & 1.00 & 86.88 & 4.18 & 15.84 & 152.97 & 144 & 1304.73 \\
\hline 20 & 1.00 & 58.62 & 5.52 & 4.59 & 166.02 & 116 & 1202.31 \\
\hline 21 & 1.00 & 112.79 & 5.64 & 42.20 & 113.12 & 160 & 1183.56 \\
\hline 22 & 1.00 & 60.52 & 5.01 & 38.17 & 163.05 & 123 & 1011.28 \\
\hline 23 & 1.00 & 58.89 & 3.95 & 38.86 & 96.63 & 121 & 766.83 \\
\hline 24 & 1.00 & 74.20 & 4.62 & 37.58 & 159.76 & 45 & 1062.98 \\
\hline 25 & 1.00 & 42.93 & 111.60 & 53.50 & 187.39 & 134 & 1435.26 \\
\hline 26 & 1.00 & 47.00 & 123.98 & 50.44 & 195.23 & 126 & 1433.87 \\
\hline 27 & 1.00 & 47.95 & 253.32 & 64.18 & 178.24 & 129 & 1390.21 \\
\hline 28 & 1.00 & 17.99 & 40.07 & 31.18 & 82.58 & 26 & 140.25 \\
\hline 29 & 1.00 & 67.37 & 64.45 & 68.28 & 94.41 & 22 & 157.28 \\
\hline 30 & 1.00 & 84.39 & 55.10 & 81.30 & 73.67 & 25 & 210.25 \\
\hline 31 & 1.00 & 79.27 & 53.10 & 79.80 & 73.31 & 27 & 252.87 \\
\hline 32 & 1.00 & 65.84 & 31.52 & 25.41 & 263.97 & 63 & 610.42 \\
\hline 33 & 1.00 & 50.27 & 32.16 & 27.85 & 372.37 & 97 & 1365.51 \\
\hline 34 & 1.00 & 42.53 & 90.95 & 26.68 & 147.01 & 62 & 659.50 \\
\hline
\end{tabular}


Table 4. The contamination factor (CF), pollution load index (PLI) and degree of contamination (DC) for heavy metals in the hydrosoils of Manzala Lake.

\begin{tabular}{|c|c|c|c|c|c|c|c|c|c|}
\hline \multirow{2}{*}{ NO } & \multicolumn{7}{|c|}{ Contamination factor (CF) } & \multirow{2}{*}{ PLI } & \multirow{2}{*}{ DC } \\
\hline & $\mathrm{Fe}$ & $\mathrm{Cu}$ & $\mathrm{Zn}$ & $\mathrm{Cr}$ & $\mathrm{Pb}$ & Co & $\mathrm{Cd}$ & & \\
\hline 1 & 0.006 & 0.20 & 0.29 & 0.30 & 0.56 & 0.45 & 4.65 & 0.28 & 6.45 \\
\hline 2 & 0.005 & 0.03 & 0.05 & 0.05 & 0.17 & 0.16 & 2.19 & 0.08 & 2.65 \\
\hline 3 & 0.006 & 0.18 & 0.70 & 0.08 & 0.71 & 0.73 & 4.85 & 0.29 & 7.25 \\
\hline 4 & 0.006 & 0.05 & 0.09 & 0.06 & 0.28 & 0.17 & 2.46 & 0.11 & 3.12 \\
\hline 5 & 0.006 & 0.24 & 0.45 & 0.14 & 0.61 & 0.65 & 4.57 & 0.29 & 6.66 \\
\hline 6 & 0.006 & 0.15 & 0.29 & 0.25 & 0.48 & 0.39 & 3.86 & 0.24 & 5.43 \\
\hline 7 & 0.006 & 0.22 & 0.57 & 0.03 & 0.95 & 0.51 & 6.79 & 0.26 & 9.09 \\
\hline 8 & 0.006 & 0.16 & 0.42 & 0.87 & 0.72 & 0.76 & 5.19 & 0.38 & 8.12 \\
\hline 9 & 0.007 & 0.67 & 0.41 & 0.04 & 0.86 & 1.07 & 4.37 & 0.31 & 7.42 \\
\hline 10 & 0.006 & 0.22 & 0.13 & 0.84 & 3.28 & 0.36 & 3.98 & 0.35 & 8.81 \\
\hline 11 & 0.007 & 0.06 & 0.66 & 0.05 & 0.19 & 1.00 & 4.09 & 0.19 & 6.05 \\
\hline 12 & 0.007 & 0.21 & 0.30 & 0.31 & 3.16 & 0.76 & 8.83 & 0.43 & 13.58 \\
\hline 13 & 0.006 & 0.08 & 0.06 & 0.07 & 0.63 & 0.66 & 6.37 & 0.18 & 7.87 \\
\hline 14 & 0.006 & 0.21 & 0.71 & 0.04 & 0.23 & 0.80 & 9.04 & 0.26 & 11.04 \\
\hline 15 & 0.007 & 0.64 & 0.22 & 0.04 & 0.77 & 0.91 & 6.45 & 0.28 & 9.03 \\
\hline 16 & 0.007 & 0.54 & 0.17 & 0.03 & 1.19 & 0.84 & 7.24 & 0.28 & 10.01 \\
\hline 17 & 0.007 & 0.59 & 0.18 & 0.03 & 1.83 & 0.95 & 5.92 & 0.30 & 9.50 \\
\hline 18 & 0.006 & 0.48 & 0.10 & 0.03 & 1.11 & 0.86 & 7.95 & 0.25 & 10.54 \\
\hline 19 & 0.007 & 0.57 & 0.10 & 0.03 & 1.00 & 0.94 & 8.52 & 0.26 & 11.16 \\
\hline 20 & 0.006 & 0.37 & 0.03 & 0.04 & 1.06 & 0.74 & 7.68 & 0.20 & 9.93 \\
\hline 21 & 0.007 & 0.74 & 0.26 & 0.04 & 0.74 & 1.05 & 7.75 & 0.31 & 10.59 \\
\hline 22 & 0.006 & 0.39 & 0.23 & 0.03 & 1.06 & 0.80 & 6.54 & 0.27 & 9.06 \\
\hline 23 & 0.006 & 0.38 & 0.24 & 0.03 & 0.63 & 0.78 & 4.96 & 0.23 & 7.02 \\
\hline 24 & 0.006 & 0.48 & 0.23 & 0.03 & 1.03 & 0.29 & 6.87 & 0.24 & 8.94 \\
\hline 25 & 0.007 & 0.28 & 0.33 & 0.77 & 1.23 & 0.87 & 9.39 & 0.47 & 12.88 \\
\hline 26 & 0.007 & 0.31 & 0.31 & 0.86 & 1.28 & 0.82 & 9.39 & 0.47 & 12.98 \\
\hline 27 & 0.007 & 0.31 & 0.40 & 1.75 & 1.17 & 0.84 & 9.11 & 0.54 & 13.59 \\
\hline 28 & 0.013 & 0.24 & 0.39 & 0.56 & 1.10 & 0.35 & 1.87 & 0.34 & 4.53 \\
\hline 29 & 0.014 & 0.94 & 0.91 & 0.95 & 1.32 & 0.31 & 2.20 & 0.52 & 6.66 \\
\hline 30 & 0.014 & 1.17 & 1.07 & 0.81 & 1.02 & 0.35 & 2.92 & 0.55 & 7.34 \\
\hline 31 & 0.014 & 1.12 & 1.07 & 0.79 & 1.04 & 0.38 & 3.57 & 0.57 & 7.97 \\
\hline 32 & 0.006 & 0.42 & 0.15 & 0.21 & 1.68 & 0.40 & 3.87 & 0.30 & 6.74 \\
\hline 33 & 0.006 & 0.32 & 0.17 & 0.22 & 2.38 & 0.62 & 8.72 & 0.37 & 12.42 \\
\hline 34 & 0.006 & 0.27 & 0.16 & 0.61 & 0.93 & 0.39 & 4.18 & 0.31 & 6.56 \\
\hline
\end{tabular}


Zahran et al.

Table 5. The geoaccmulation index (Igeo) of heavy metals in the hydrosoils of Manzala Lake.

\begin{tabular}{|c|c|c|c|c|c|c|c|}
\hline \multirow{2}{*}{ NO } & \multicolumn{7}{|c|}{ Geoaccmulation index (Igeo) } \\
\hline & $\mathrm{Fe}$ & $\mathrm{Cu}$ & $\mathrm{Zn}$ & $\mathrm{Cr}$ & $\mathrm{Pb}$ & Co & $\mathrm{Cd}$ \\
\hline 1 & -2.37 & -0.88 & -0.72 & -0.69 & -0.43 & -0.53 & 0.49 \\
\hline 2 & -2.45 & -1.73 & -1.48 & -1.48 & -0.94 & -0.98 & 0.16 \\
\hline 3 & -2.36 & -0.91 & -1.32 & -0.31 & -0.33 & -0.31 & 0.51 \\
\hline 4 & -2.42 & -1.48 & -1.39 & -1.19 & -0.73 & -0.93 & 0.21 \\
\hline 5 & -2.37 & -0.80 & -1.05 & -0.50 & -0.39 & -0.36 & 0.48 \\
\hline 6 & -2.38 & -1.01 & -0.81 & -0.69 & -0.49 & -0.58 & 0.41 \\
\hline 7 & -2.39 & -0.83 & -1.68 & -0.39 & -0.20 & -0.47 & 0.66 \\
\hline 8 & -2.36 & -0.98 & -0.26 & -0.53 & -0.32 & -0.29 & 0.54 \\
\hline 9 & -2.36 & -0.35 & -1.62 & -0.54 & -0.24 & -0.15 & 0.46 \\
\hline 10 & -2.38 & -0.84 & -0.28 & -1.04 & 0.34 & -0.62 & 0.42 \\
\hline 11 & -2.36 & -1.43 & -1.54 & -0.33 & -0.90 & -0.18 & 0.44 \\
\hline 12 & -2.36 & -0.85 & -0.71 & -0.67 & 0.32 & -0.30 & 0.77 \\
\hline 13 & -2.37 & -1.29 & -1.37 & -1.37 & -0.38 & -0.36 & 0.63 \\
\hline 14 & -2.36 & -0.85 & -1.57 & -0.30 & -0.81 & -0.27 & 0.78 \\
\hline 15 & -2.36 & -0.37 & -1.65 & -0.80 & -0.29 & -0.22 & 0.63 \\
\hline 16 & -2.36 & -0.44 & -1.67 & -0.92 & -0.10 & -0.25 & 0.68 \\
\hline 17 & -2.36 & -0.41 & -1.67 & -0.90 & 0.09 & -0.20 & 0.60 \\
\hline 18 & -2.37 & -0.49 & -1.75 & -1.16 & -0.13 & -0.24 & 0.72 \\
\hline 19 & -2.36 & -0.42 & -1.74 & -1.16 & -0.18 & -0.20 & 0.75 \\
\hline 20 & -2.37 & -0.60 & -1.63 & -1.71 & -0.15 & -0.31 & 0.71 \\
\hline 21 & -2.36 & -0.31 & -1.61 & -0.73 & -0.31 & -0.16 & 0.71 \\
\hline 22 & -2.37 & -0.58 & -1.67 & -0.78 & -0.15 & -0.28 & 0.64 \\
\hline 23 & -2.37 & -0.60 & -1.77 & -0.78 & -0.38 & -0.28 & 0.52 \\
\hline 24 & -2.37 & -0.50 & -1.70 & -0.79 & -0.16 & -0.71 & 0.66 \\
\hline 25 & -2.36 & -0.73 & -0.31 & -0.63 & -0.09 & -0.23 & 0.80 \\
\hline 26 & -2.36 & -0.69 & -0.27 & -0.66 & -0.07 & -0.26 & 0.80 \\
\hline 27 & -2.36 & -0.68 & 0.04 & -0.55 & -0.11 & -0.25 & 0.78 \\
\hline 28 & -2.05 & -0.80 & -0.45 & -0.56 & -0.13 & -0.64 & 0.10 \\
\hline 29 & -2.03 & -0.20 & -0.22 & -0.20 & -0.05 & -0.68 & 0.17 \\
\hline 30 & -2.03 & -0.11 & -0.29 & -0.12 & -0.17 & -0.64 & 0.29 \\
\hline 31 & -2.03 & -0.13 & -0.30 & -0.12 & -0.16 & -0.60 & 0.38 \\
\hline 32 & -2.37 & -0.56 & -0.88 & -0.97 & 0.05 & -0.57 & 0.41 \\
\hline 33 & -2.37 & -0.67 & -0.86 & -0.93 & 0.20 & -0.38 & 0.76 \\
\hline 34 & -2.37 & -0.75 & -0.41 & -0.95 & -0.21 & -0.58 & 0.45 \\
\hline
\end{tabular}




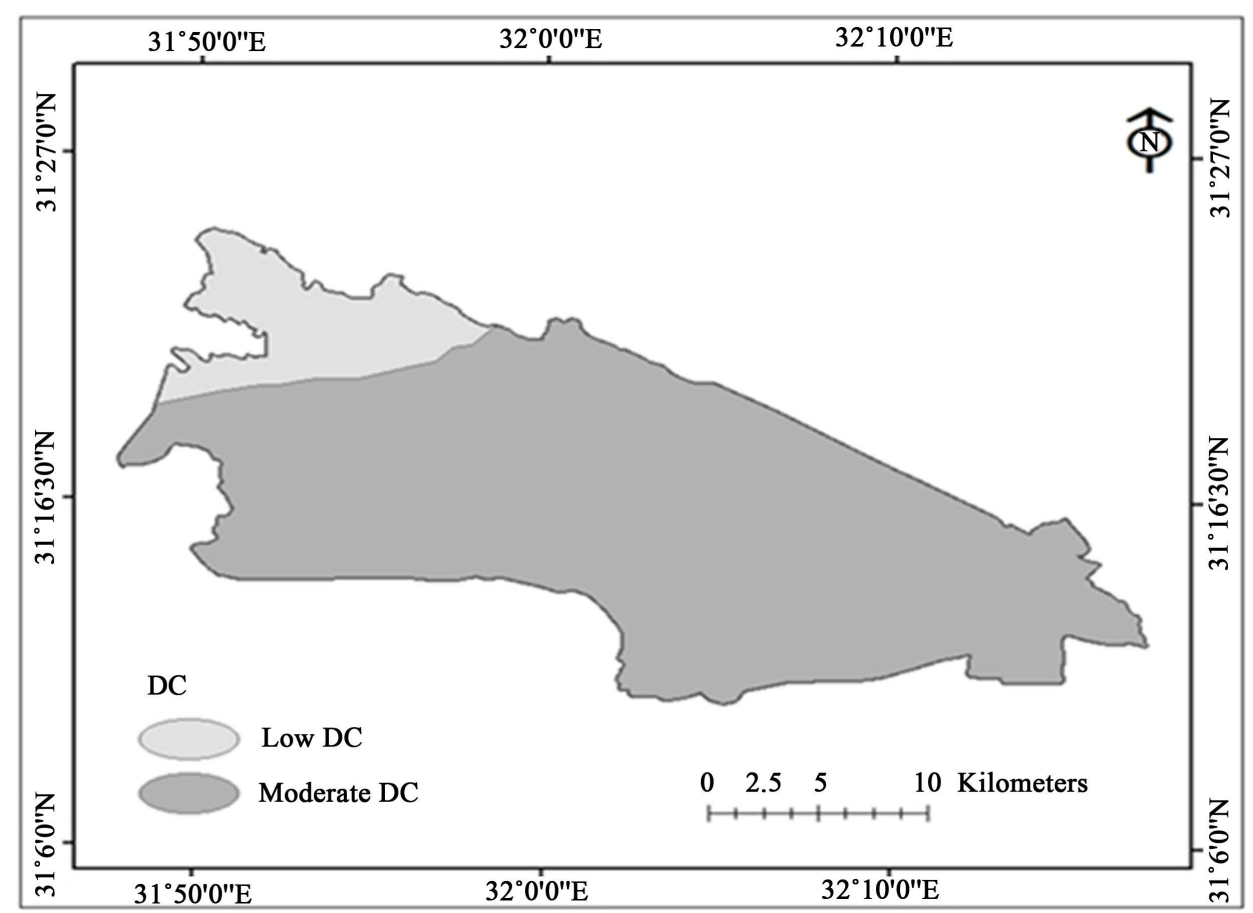

Figure 4. The spatial distribution of contamination degree (DC) of heavy metals in the hydrosoils of Manzala Lake.

Table 6. Pearson-moment correlation (r) between the concentrations of heavy metals in the hydrosoils and water of Manzala Lake.

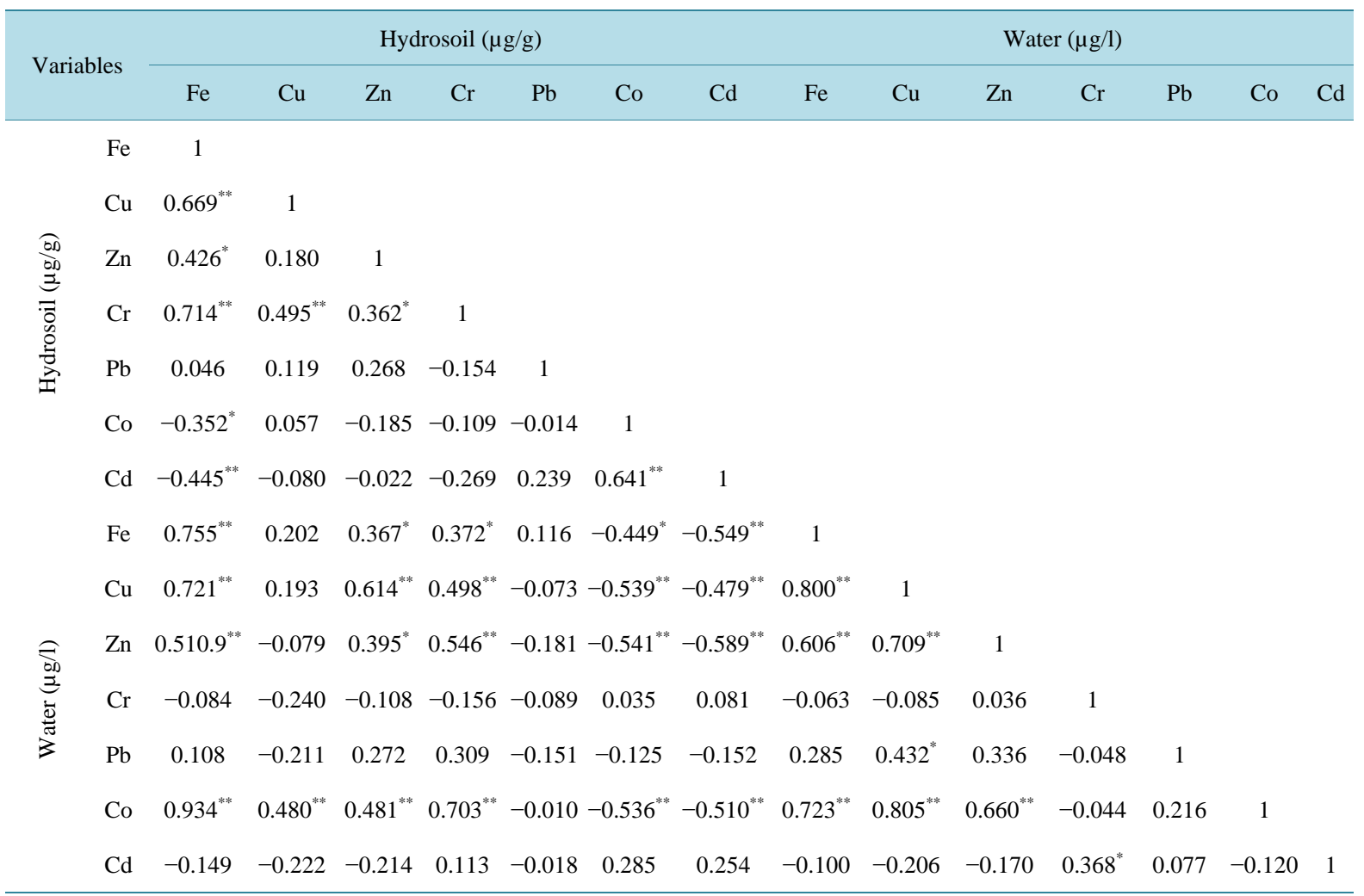

${ }^{* *}$ Correlation is significant at the 0.01 level. ${ }^{*}$ Correlation is significant at the 0.05 level. 


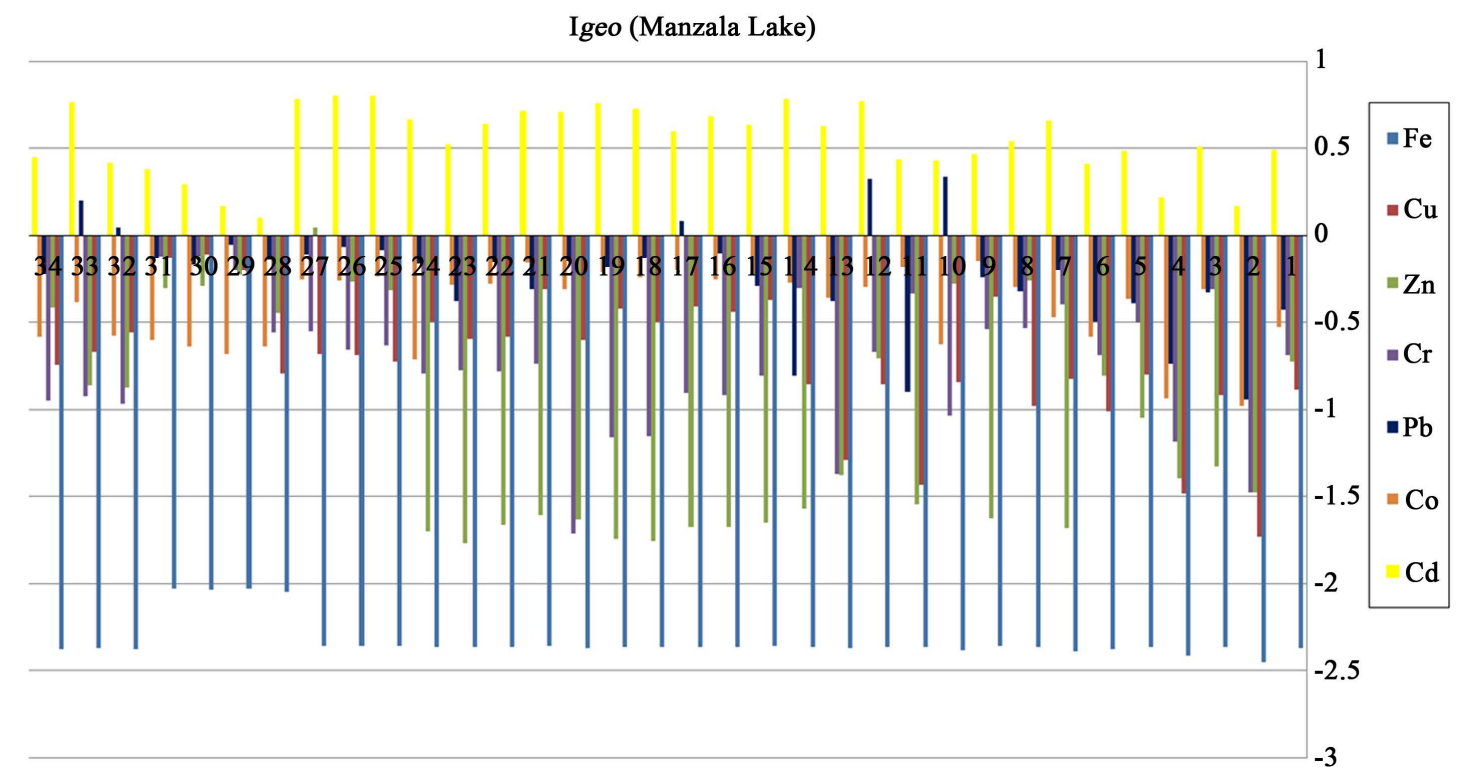

Figure 5. The geoaccumulation index for the heavy metals in the hydrosoils of Manzala Lake.

\section{Conclusion}

It could be concluded that the geospatial tools such as ordinary Kriging could be very helpful in evaluating and studying the spatial distribution of heavy metals in both water and sediment of Manzala Lake in Egypt. The obtained results clearly demonstrate that Manzala Lake is highly contaminated with $\mathrm{Fe}, \mathrm{Cd}, \mathrm{Pb}$ and $\mathrm{Cr}$ due to the continuous discharge of different pollutants into it. It can also be concluded that the southern drains namely, Bahr El-Baqar, Ramsis, El-Matria, Hadous, Faraskur, El-Serw and Lissa El-Gamalia play an important role in causing a severe pollution in Manzala Lake. This is especially in the southeastern parts of the lake, which receive great quantities of effluents from Bahr El-Baqar, Hadous and Ramsis drains. From the sequence of enrichment factor (EF), for heavy metals in the hydrosoils of Manzala Lake, cadmium is more abundant than other metals, whereas $\mathrm{Cu}$ shows the lowest appearance. Contamination factor (CF) showed that only nearby Bahr El-Baqar drain (moderate CF) and the CF of cadmium showed moderate, considerable and very high CF there. From the pollution load index (PLI) and degree of contamination (DC), it is showed that there is no appreciable pollution in Lake Manzala. Geo-accumulation index (Igeo) results of lead and cadmium showed moderately polluted category in all locations. Great efforts and cooperation between different authorities are needed to protect the lake from pollution and reduce the environmental risk. This can be achieved through the treatment of agricultural, industrial, and sewage discharge. Regular evaluation of pollutants in the lake is also very important.

\section{References}

[1] Saeed, S.M. and Shaker, I.M. (2008) Assessment of Heavy Metals Pollution in Water and Sediments and Their Effect on Oreochromis Niloticus in the Northern Delta Lakes, Egypt. 8th International Symposium on Tilapia in Aquaculture, 475-490.

[2] Elewa, A.A., Saad, E.A., Shehata, M.B. and Ghallab, M.H. (2007) Studies on the Effect of Drain Effluents on the Water Quality of Lake Manzala. Egyptian Journal of Aquatic Biology and Fisheries, 11, 65-78.

[3] APHA (1989) Standard Methods for the Examination of Water and Wastewater, Part 3, Determination of Metals. 17th, American Public Health Association, Washington DC, 164.

[4] Oregioni, B. and Aston, S.R. (1984) The Determination of Selected Trace Metals in Marine Sediments by Flameless/ Flam-Atomic Absorption Spectrophotometry. IAEA Monaco Laboratory Internal Report.

[5] ESRI (2012) ArcGIS Geostatistical Analyst Tutorial (ArcGIS®10.1). ESRI, USA.

[6] Seshan, B.R.R., Natesan, U. and Deepthi, K. (2010) Geochemical and Statistical Approach for Evaluation of Heavy Metal Pollution in Core Sediments in Southeast Coast of India. International Journal of Environmental Science and 
Technology, 7, 291-306. http://dx.doi.org/10.1007/BF03326139

[7] Liaghati, T., Preda, M. and Cox, M. (2003) Heavy Metal Distribution and Controlling Factors within Coastal Plain Sediments, Bells Creek Catchments, Southeast Queensland, Australia. Environment International, 29, 935-948. http://dx.doi.org/10.1016/S0160-4120(03)00060-6

[8] Tomilson, D.C., Wilson, D.J., Harris, C.R. and Jeffrey, D.W. (1980) Problem in Assessment of Heavy Metals in Estuaries and the Formation of Pollution Index. Helgoländer Meeresuntersuchungen, 33, 566-575. http://dx.doi.org/10.1007/BF02414780

[9] Saad, M.A.H., Ezzat, A.A., El-Rayis, O.A. and Hafez, H. (1981) Occurrence and Distribution of Chemical Pollutants in Lake Mariut, Egypt. II. Heavy Metals. Water, Air, and Soil Pollution, 16, 401-407. http://dx.doi.org/10.1007/BF01048131

[10] Environmental Protection Agency (2002) National Recommended Water Quality Criteria. EPA, USA, 822-R-02-047.

[11] Muller, G. (1969) Index of Geo-Accumulation in Sediments of the Rhine River. GeoJournal, 2, 108-118.

[12] Buccolieri, A., Buccolieri, G. and Cardellicchio, N. (2006) Heavy Metals in Marine Sediments of Taranto Gulf (Ionian Sea, Southern Italy). Marine Chemistry, 99, 227-235. http://dx.doi.org/10.1016/j.marchem.2005.09.009

[13] El-Alfy, M.A. (2011) An Integrated Approach for Monitoring the Impact of Industrial Activities on the Northeastern Part of Manzala Lagoon, Egypt. Master’s Thesis, Environmental Sciences Department, Damietta Faculty of Science, Mansoura University, Mansoura.

[14] Arain, M.B., Kazi, T.G., Jamali, M.K., Afridi, H.I., Baig, J.A., Jalbani, N. and Shah, A. (2008) Evaluation of PhysicoChemical Parameters of Manchar Lake Water and Their Comparison with Other Global Published Values. Pakistan Journal of Analytical \& Environmental Chemistry, 9, 101-109.

[15] Ali, M. and Abdel-Satar, A. (2005) Studies of Some Heavy Metals in Water, Sediment, Fish and Fish Diets in Some Fish Farms in EL-Fayoum Province. Egyptian Journal of Aquatic Research, 31, 261-273.

[16] Bahnasawy, M.H., Khidr, A.A. and Dheina, N.A. (2009) Assessment of Heavy Metals Concentrations in Water, Plankton and Fish of Lake Manzala, Egypt. Egyptian Journal of Aquatic Biology and Fisheries, 13, 117-133.

[17] Bahnasawy, M., Khidr, A. and Dheina, N. (2011) Assessment of Heavy Metal Concentrations in Water, Plankton, and Fish of Lake Manzala, Egypt. Turkish Journal of Zoology, 35, 271-280.

[18] EPA (1986) Quality Criteria for Water. EPA 440/5-86-001. Office of Water Regulations and Standards, Washington DC.

[19] Nagpal, N.K. (2004) Technical Report, Water Quality Guidelines for Cobalt. Water Quality—Standards—British Columbia. Ministry of Water, Land and Air Protection, 6.

[20] El-Serehy, H.A., Aboulela, H., Al-Misned, F., Kaiser, M., Al-Rasheid, K. and Ezz El-Din, H. (2012) Heavy Metals Contamination of a Mediterranean Coastal Ecosystem, Eastern Nile Delta, Egypt. Turkish Journal of Fisheries and Aquatic Sciences, 12, 751-760.

[21] Environment Canada (1997) Canadian Water Quality Guidelines for Chromium. Supporting Document, Environment Canada, Science Policy and Environmental Quality Branch, Ottawa.

[22] Hamed, Y.A., Abdelmoneim, T.S., ElKiki, M.H., Hassan, M.A. and Berndtsson, R. (2013) Assessment of Heavy Metals Pollution and Microbial Contamination in Water, Sediments and Fish of Lake Manzala, Egypt. Life Science Journal, 10, 86-99.

[23] European Union (2002) Heavy Metals in Wastes, European Commission on Environment. http://ec.europa.eu/environment/waste/studies/pdf/heavy_metalsreport.pdf

[24] Saeed, S.M. and Mohammed, M.A. (2012) Influence of Physico-Chemical Characteristics of Water on Metals Accumulation in Water and Tilapia Zillii Inhabiting Different Habitats in Egypt. Journal of the Arabian Aquaculture Society, 7, 29-50.

[25] El-Bady, M.S.M. (2014) Spatial Distribution of Some Important Heavy Metals in the Soils South of Manzala Lake in Bahr El-Baqar Region, Egypt. Nova Journal of Engineering and Applied Sciences, 2, 1-15.

[26] Müller, G. (1981) Die Schwermetallbelastung der sedimente des Neckars und seiner Nebenflusse: Eine Bestandsaufnahme. Chemical Zeitung, 105, 157-164.

[27] Dan, S.F., Umoh, U.U. and Osabor, V.N. (2014) Seasonal Variation of Enrichment and Contamination of Heavy Metals in the Surface Water of Qua Iboe River Estuary and Adjoining Creeks South-South Nigeria. Journal of Oceanography and Marine Science, 5, 45-54. http://dx.doi.org/10.5897/JOMS2013.0103 